\title{
Economic Impacts of the Florida Citrus Industry in 2007-081
}

Mohammad Rahmani and Alan W. Hodges ${ }^{2}$

\section{Introduction}

In spite of the adverse effects of hurricanes and diseases such as citrus canker and citrus greening, the citrus industry remains a major part of Florida's agricultural and natural resource economy. Between the 2003-04 and 2007-08 production seasons, total citrus production acreage and volume declined by 20 and 30 percent, respectively; however, the total on-tree value of citrus fruit increased by 36 percent ( $\$ 892$ to $\$ 1,212$ million) due to higher prices (Citrus Summary 2007-08).

This paper presents estimates of the total economic impacts of the Florida citrus industry on the state economy based on production values for the 2007-08 production season. Estimates are presented for citrus fruit for the fresh market and for citrus fruit for processed juice and byproducts. Economic impacts are expressed in terms of output, employment, value added, labor income, indirect business taxes, and other property incomes. This study updates previous studies for the 1999-2000 and 2003-04 production seasons (Hodges et al. 2001, 2006).

\section{Methods}

The total economic impacts of the Florida citrus industry in 2007-08 were evaluated using published values for citrus fresh fruit production, processed juices, and byproducts, together with a regional input-output model for Florida. Data for citrus fruit were taken from reports by the United States Department of Agriculture/National Agricultural Statistics Service (USDA/NASS), the Florida Department of Citrus, and the Florida Agricultural Statistics Service (FASS). Data on the value of processed citrus juice and quantities of citrus byproducts were provided by the Florida Department of Citrus, Economic Market Research. Data on the quantity of citrus byproducts were provided by the Florida Citrus Processors Association, and data on the values of byproducts were taken from Feedstuffs Magazine, and quotes from Florida Distillers, Inc. and Peace River Citrus Products.

The IMPLAN Pro economic impact and social accounting software package, licensed to the University of Florida by the Minnesota IMPLAN Group, Inc. (MIG), was used to develop a regional

1. This is EDIS document FE802, a publication of the Food and Resource Economics Department, Florida Cooperative Extension Service, Institute of Food and Agricultural Sciences, University of Florida, Gainesville, FL. Published July 2009. Please visit the EDIS website at http://edis.ifas.ufl.edu.

2. Mohammad Rahmani, coordinator of economic analysis, and Alan W. Hodges, extension scientist, Food and Resource Economics Department, Florida Cooperative Extension Service, Institute of Food and Agricultural Sciences, University of Florida, Gainesville, FL.

The use of trade names in this publication is solely for the purpose of providing specific information. UF/IFAS does not guarantee or warranty the products named, and references to them in this publication does not signify our approval to the exclusion of other products of suitable composition.

The Institute of Food and Agricultural Sciences (IFAS) is an Equal Opportunity Institution authorized to provide research, educational information and other services only to individuals and institutions that function with non-discrimination with respect to race, creed, color, religion, age, disability, sex, sexual orientation, marital status, national origin, political opinions or affiliations. U.S. Department of Agriculture, Cooperative Extension Service, University of Florida, IFAS, Florida A. \& M. University Cooperative Extension Program, and Boards of County Commissioners Cooperating. Millie Ferrer, Interim Dean 
input-output model of the Florida economy with adjustments for the citrus industry. IMPLAN, an acronym for Impact Analysis for Planning, is an input-output modeling system that enables the estimation of the overall effects of changes in final demand for one or more industries in a defined region through the use of economic multipliers. Multipliers measure total changes in output, income, employment, or value added for a given change in direct output or employment, and estimate three components of change within the local area: direct effects, representing the initial change in the industry in question; indirect effects, representing changes in inter-industry transactions as supplying industries respond to changes in demands from the directly affected industries; and induced effects, reflecting changes in local spending that result from income changes in industry employee households. Social Accounting Matrix (SAM) multipliers in IMPLAN account for capital investment, taxes, and transfer payments such as social security, welfare, retirement pensions, and savings by household.

Regional models may be constructed with IMPLAN for a single county, groups of contiguous counties, or an entire state or region. In this case, the region of interest was defined as the state of Florida. Regional data for the model represent 2007, the most recent information available from the U.S. System of National Accounts and from the Regional Economic Information System maintained by the U.S. Commerce Department. Information used in the model is specific to the state for industry output, employment, income, and trade while national averages are used to estimate transactions between industries. The model was constructed with all social accounts endogenous, including households, governments (state/local, federal), and capital investment.

Four industry sectors in IMPLAN were used to analyze the Florida citrus industry: fruit farming (\#4), frozen foods (\#53), canned fruit and vegetable juices (\#54), and wholesale trade (\#319). These industry sectors are defined based on the primary product or service produced under the North American Industry Classification System (NAICS). It should be noted that the 2007 NAICS classification was reduced from 509 to 440 industry sectors. The output value of each major type of product was specified as an impact event in the appropriate industry sector: fresh market citrus fruit in the fruit farming sector, frozen citrus juices (FCOJ) in the frozen foods sector, chilled citrus juices in the canned (bottled) juices sector, and packed fresh citrus fruit in the wholesale trade sector. Values of processed byproducts were entered as impact events to the two processing sectors in proportion to their primary product values. Also, the export and local consumption values of citrus juice and byproducts were treated separately; only the direct impacts were considered for local consumption, since these values do not necessarily represent a change in overall regional economic activity.

Several adjustments were made to the IMPLAN model to reflect the special characteristics of the Florida citrus industry as distinguished from the national economy for fruit farming and frozen/canned food processing, which includes a variety of other food commodities. The set of inputs purchased by these industries, described by production functions, is what drives the estimates of indirect and induced impacts. The production functions for the two processing sectors were adjusted so that purchases from the fruit farming sector represented the only contributing sector in the model (i.e., other agricultural sectors were removed from the model). The production function for the fruit farming sector was adjusted based on budgeted production costs reported by Muraro (2007-2008) for cultural programs with and without canker-greening. Production expenditures are shown in Tables 8 and 9 for each cultural program, for the major citrus types, and for the production regions in Florida, including both fresh and processed early-season and mid-season oranges, Valencia oranges, and white and red grapefruit in the central, southern, and Indian River regions, respectively. Based on the average yield per acre for each citrus variety, the cost per box of produced citrus was estimated for each type and cultural program. Total cost of production for all types of citrus fruit is the number of boxes produced multiplied by the cost of production per box. The total expenditures then were categorized by fresh and processed products. Based on industry expert opinions, the Florida citrus production expenditure budget was constructed under the assumption that 
two-thirds of citrus growers follow the recommended citrus canker-greening cultural program and one-third of citrus growers do not follow the canker-greening program (Table 1). Industry purchases from other sectors included greenhouse and nursery products, agricultural support services, petrochemical manufacturing, fertilizer mixing and manufacturing, pesticides and agricultural chemicals, monetary authorities and depository credit intermediaries, and other state and local government enterprises. Many of the cultural operations were treated as labor inputs to production and represent value-added rather than industry purchases.

\section{Results and Discussion}

The value of citrus fruit production for the fresh market and for processing is summarized by citrus variety in Tables 2 and 3. In the 2007-08 season, total citrus fruit production in Florida was 203.8 million boxes, including 170 million boxes of early season, mid-season, Temple, Navel, and Valencia oranges; 27 million boxes of grapefruit; and 7 million boxes of specialty citrus (tangelos and tangerines). Of the total citrus crop, some 20 million boxes (10 percent) were produced for the fresh market and 184 million boxes ( 90 percent) were utilized for processing (Table 2). About 50 percent of the red seedless grapefruit was produced for the fresh market, while 79 percent of the white seedless grapefruit and more than 96 percent of the oranges were processed for juice. Average free on board (F.O.B.) prices for fresh market fruit sold from packinghouses ranged from $\$ 18.40$ for tangelos to $\$ 26.20$ for tangerines and mandarins. Average packing house door (P.H.D.) prices received from producers for fresh fruit were $\$ 11.30$ per box for early, mid-season, and Navel oranges; $\$ 10.40$ for Valencia oranges; and $\$ 12.15$ to $\$ 13.00$ for grapefruit (Table 2). The total value of Florida citrus fruit based on delivered prices in 2007-08 was $\$ 1.76$ billion, with fresh fruit accounting for $\$ 253$ million and processed fruit accounting for $\$ 1.50$ billion. The value of red seedless grapefruit for the fresh market was more than $\$ 113$ million, or 45 percent of the total value of fresh market citrus. Valencia oranges represented 54 percent of the processed fruit market value, while early, mid-season, and Navel oranges accounted for 43 percent. The total values of Florida fresh and processed citrus as well as the value of fresh packinghouse product values based on F.O.B. prices are shown in Table 3. The fresh wholesale margin is the difference between what is paid by packinghouses (delivered prices) and the value of shipped fruit (F.O.B. prices).

The total (F.O.B.) value of citrus juice in the 2007-08 production season was $\$ 3.45$ billion, including $\$ 2.37$ billion for chilled juice and \$1.08 billion for frozen juice (Table 4). More than $\$ 3.25$ billion, or 94 percent of the citrus juice was exported outside of Florida to other states or foreign countries, while only 6 percent was consumed in Florida. In addition to orange and grapefruit juices, the citrus processing industry produces several other important byproducts, including citrus pulp and meal, molasses, and citrus oil. The essential oil D-limonene, recovered from the distilled extracts of fruit peel and seeds (citrus oil), is used for a variety of chemical products such as cleaners, disinfectants, flavors, and fragrances. Citrus pulp and meal, and molasses are sold as livestock feed ingredients. During the 2007-08 production season, Florida citrus processors produced 722,895 tons of citrus pulp and meal, 57,058 tons of molasses, and more than 24 million pounds of citrus oil. The total value of these byproducts in 2007-08 was about $\$ 136$ million (Table 5 ), with citrus pulp and meal representing about 74 percent of the byproduct values.

Total economic impacts estimated for the Florida citrus industry in 2007-08 are summarized in Table 6 . The direct output or sales revenue was more than $\$ 4.02$ billion and the total output impact of the industry exceeded $\$ 8.9$ billion, including $\$ 3.57$ billion from citrus fruit for juice production, $\$ 601$ million from citrus fruit for fresh market, $\$ 4.32$ billion from citrus juice and byproducts, and $\$ 415$ million from fresh citrus marketing (packing) margins. The indirect output impacts resulting from purchases of inputs from other industry sectors were $\$ 1.37$ billion, while the induced output impacts resulting from consumer spending by employee households were $\$ 3.51$ billion. The ratio between the total output impact and direct output implies an overall multiplier effect of about 2.2. These multiplier effects are significant because the export-based 
nature of the Florida citrus industry brings new money into the state economy.

The Florida citrus industry had a total employment impact of 75,828 jobs, including 27,425 jobs directly in the industry, plus 16,967 indirect jobs in allied industries, and 31,436 jobs created by employee spending (induced effect). These employment impacts represent both full-time and part-time jobs, and are not adjusted to a full-time equivalent basis.

Total value-added impacts were $\$ 4.62$ billion, including $\$ 1.72$ billion in the citrus industry and $\$ 2.90$ billion in other sectors. Value added is a broad measure of labor and property income generated, and is equivalent to industry output less industry purchases. Labor income impacts amounted to about $\$ 2.77$ billion, which represented all wages and salary earnings by industry employees and proprietor's income to business owners. Other property income impacts of $\$ 1.45$ billion represented rents, interest, dividends, royalties, etc. Indirect business tax impacts were \$310 million, which included most forms of local and state taxes, such as property taxes, sales taxes, water management district levies, intangible taxes, motor fuel and vehicle taxes, excise taxes, etc., but did not include federal income taxes.

Total economic impacts of the Florida citrus industry by major industry group are shown in Table 7 . Naturally, the largest impacts occurred in the agriculture and manufacturing groups, where the direct impacts occurred from fruit farms and citrus processing. Output impacts in agriculture and manufacturing were $\$ 2.06$ billion and $\$ 2.48$ billion, respectively. Large output impacts also occurred in wholesale trade (\$548 million); real estate and rentals (\$534 million); government (\$428 million); construction ( $\$ 409$ million); finance and insurance (\$363 million); health and social services (\$347 million); professional, scientific, and technical services ( $\$ 318$ million); and retail trade ( $\$ 312$ million). Employment impacts for agriculture $(30,568$ jobs $)$ were much greater than for manufacturing $(7,607$ jobs $)$ due to the labor-intensive nature of agriculture, particularly for citrus fruit harvesting. Important employment impacts also occurred in government $(5,285$ jobs $)$, retail trade
(4,682 jobs), and health and social services $(4,143$ jobs). These impacts in other industries indicate the significant linkages of the citrus industry throughout the Florida economy.

While the citrus industry still represents a major agricultural activity in Florida, these economic impact results for 2007-08 were lower compared to the previous study using 2003-04 data. The total output impacts decreased from $\$ 9.29$ billion in 2003-04 to \$8.91 billion in 2007-08; employment impacts declined from 76,336 to 75,827 jobs; and value added shrank from $\$ 4.87$ billion to $\$ 4.62$ billion. On the other hand, the measures for labor income increased from $\$ 2.73$ billion to nearly $\$ 2.77$ billion, and indirect business taxes increased from \$287 million to \$310 million.

These economic impact estimates are based on well-documented values for citrus products; however, certain limitations of the analysis should be considered when interpreting the results. First, the budget information for citrus fruit production was aggregated into a relatively small number of IMPLAN sectors, which may lead to underestimation of the linkages to other sectors of the state's economy. Second, there was no specific information available for the citrus processing sector, other than purchases from the fruit farming sector, which would enable adjustment of the production function for this sector. To more accurately estimate the economic impacts of this large sector would require further details on processing expenditures. Finally, the change in NAICS classification, which reduced the number of industry sectors in the model, may have affected the estimated multiplier effects.

\section{References}

Feedstuffs. 2008. Price data for citrus pulp and meal. Feedstuffs, the Weekly Newspaper for Agribusiness, Minnetonka, MN (various issues).

FCPA. 2009. Statistical Summary 2007-2008 Season. Florida Citrus Processors Association, Winter Haven, FL.

FDACS/FASS. 2009. Citrus Summary, 2007-08. Florida Department of Agriculture and Consumer Services, Florida Agricultural Statistics 
Service, Tallahassee, FL (March 2009).

http://www.nass.usda.gov/fl

Hodges, A.W, E. Phillippakos, W.D. Mulkey, T. Spreen, and R. Muraro. 2001. Economic Impact of Florida's Citrus industry, 1999-2000. Economic Information Report 01-02, Food and Resource Economics Department, University of Florida, Gainesville, FL (July).

http://www.economicimpact.ifas.ufl.edu/publications/ Commodity/er01-2-citrus.pdf

Hodges, A.W., M. Rahmani, and W.D. Mulkey. 2006. Economic impact of Florida's citrus industry, 2003-04. Electronic Data Information Source (EDIS) FE633. Food \& Resource Economics Department, University of Florida, Gainesville, FL. http://edis.ifas.ufl.edu/FE633

Minnesota IMPLAN Group (MIG). IMPLAN economic impact and social accounting software and 2007 data for Florida. Minnesota IMPLAN Group, Inc., Stillwater, MN. http://www.implan.com

Muraro, R.P. 2009. Summary of 2007-2008 Citrus Budget for the Central Florida (Ridge) Production Region. Citrus Research and Education Center, University of Florida, Lake Alfred, FL. http://www.crec.ifas.ufl.edu/extension/economics/pdf/ CF_Budget_Summ_2007_2008.pdf

Muraro, R.P. 2009. Summary of 2007-2008 Citrus Budget for the Indian River Production Region. Citrus Research and Education Center, University of Florida, Lake Alfred, FL.

http://www.crec.ifas.ufl.edu/extension/economics/pdf/ IR_Budget_Summ_2007-2008.pdf

Muraro, R.P. 2009. Summary of 2007-2008 Citrus Budget for the Southwest Florida Production Region. Citrus Research and Education Center, University of Florida, Lake Alfred, FL. http://www.crec.ifas.ufl.edu/extension/economics/pdf/ SW_Budget_Summ_2007_2008.pdf

USDA/NASS. 2008. Citrus Fruits, 2008 Summary (Fr Nt 3-1 08). United States Department of Agriculture, National Agricultural Statistics Service (USDA/NASS), Washington, D.C. (September). http://www.nass.usda.gov/ 
Economic Impacts of the Florida Citrus Industry in 2007-08

Table 1. Industry purchases for Florida citrus fruit production, by IMPLAN sector, 2007-08.

\begin{tabular}{|lrrr|}
\hline \hline IMPLAN Sector & Fresh Fruit & Processed Fruit & $\begin{array}{r}\text { TOTAL } \\
\text { (Processed + } \\
\text { Fresh) }\end{array}$ \\
\hline Greenhouse \& nursery products (6) & 3.6 & 34.8 & 38.4 \\
Agricultural support services (19) & 80.7 & 710.5 & 791.2 \\
Petrochemical manufacturing (120) & 6.1 & 42.3 & 48.4 \\
Fertilizer mixing \& manufacturing (130) & 17.9 & 205.5 & 223.5 \\
Pesticides \& agricultural chemicals (131) & 19.7 & 168.6 & 188.3 \\
Monetary authorities \& depository credit intermediaries (354) & 17.9 & 170.0 & 187.9 \\
Other state \& local government enterprises (432) & 10.0 & 73.7 & 83.7 \\
\hline Total intermediary commodity purchases & $\underline{155.9}$ & $1,405.4$ & $\mathbf{1 , 5 6 1 . 4}$ \\
\hline Indirect business taxes & 10.0 & 73.7 & 83.7 \\
Total value-added & & $\mathbf{8 7 4 . 9}$ \\
\hline Total sales & & $\mathbf{1 , 7 5 5 . 7}$ \\
\hline \hline
\end{tabular}

Table 2. Florida citrus fruit production values and average prices for Florida, 2007-08.

\begin{tabular}{|c|c|c|c|c|c|c|}
\hline \multirow[b]{2}{*}{ Citrus Type } & \multicolumn{3}{|c|}{ Production Volume } & \multicolumn{3}{|c|}{ Average Price } \\
\hline & Fresh & Processed & Total & Fresh $^{*}$ & Processed* $^{*}$ & $\begin{array}{c}\text { Packed } \\
\text { Fresh } \\
\text { (FOB) }\end{array}$ \\
\hline & \multicolumn{3}{|c|}{$(1,000$ boxes $)$} & \multicolumn{3}{|c|}{ (dollars per box) } \\
\hline Early, mid-season, and Navel oranges & 3,885 & 79,615 & 83,500 & $\$ 11.30$ & $\$ 8.05$ & $\$ 20.30$ \\
\hline Valencia oranges & 1,977 & 84,723 & 86,700 & $\$ 10.40$ & $\$ 9.49$ & $\$ 19,40$ \\
\hline White seedless grapefruit & 1,905 & 7,095 & 9,000 & $\$ 12.15$ & $\$ 2.73$ & $\$ 20.90$ \\
\hline Red seedless grapefruit & 8,716 & 8,884 & 17,600 & $\$ 13.00$ & $\$ 2.65$ & $\$ 21.40$ \\
\hline Tangelos & 432 & 1,068 & 1,500 & $\$ 9.10$ & $\$ 4.61$ & $\$ 18.40$ \\
\hline Tangerines and Mandarins & 3,282 & 2,218 & 5,500 & $\$ 14.70$ & $\$ 4.45$ & $\$ 26.20$ \\
\hline Total & 20,197 & 183,603 & 203,800 & & & \\
\hline
\end{tabular}


Economic Impacts of the Florida Citrus Industry in 2007-08

Table 3. Value of fresh and processed Florida citrus fruit and packinghouse margin, 2007-08.

\begin{tabular}{|c|c|c|c|c|c|}
\hline Citrus Type & $\begin{array}{l}\text { Value } \\
\text { Fresh }\end{array}$ & $\begin{array}{c}\text { Value } \\
\text { Processed }\end{array}$ & $\begin{array}{r}\text { Total Value } \\
\text { (delivered-in } \\
\text { basis) }\end{array}$ & $\begin{array}{r}\text { Total Value } \\
\text { Fresh } \\
\text { Shipments }\end{array}$ & $\begin{array}{r}\text { Fresh } \\
\text { Packinghouse } \\
\text { Marketing } \\
\text { Margin* }\end{array}$ \\
\hline & \multicolumn{5}{|c|}{ (million dollars) } \\
\hline Early, mid-season, and Navel oranges & 44 & 641 & 685 & 79 & 35 \\
\hline White seedless grapefruit & 23 & 19 & 42 & 40 & 17 \\
\hline Red seedless grapefruit & 113 & 24 & 137 & 187 & 73 \\
\hline Tangelos & 4 & 5 & 9 & 8 & 4 \\
\hline
\end{tabular}

Table 4. Value of Florida frozen and canned citrus juice for local consumption and export, 2007-08.

\begin{tabular}{|c|c|c|c|}
\hline Product & Out-of-State Shipments & In-State Consumption & Total Value \\
\hline & \multicolumn{3}{|c|}{ (million dollars) } \\
\hline Frozen orange juice & 972.4 & 57.5 & $\overline{1,029.9}$ \\
\hline Chilled \& canned (bottled) orange juice & $2,141.0$ & 132.7 & $2,273.7$ \\
\hline Frozen grapefruit juice & 50.6 & 1.5 & 52.1 \\
\hline Chilled \& canned (bottled) grapefruit juice & 87.8 & 4.3 & 92.1 \\
\hline Total for all citrus juice products & $3,251.8$ & 196.0 & $3,447.8$ \\
\hline
\end{tabular}

Table 5. Volume and value of Florida processed citrus byproducts, 2007-08.

\begin{tabular}{|lrrrr}
\hline \hline Product & Production Volume & Unit & Price & Total Value \\
\hline & & & (dollars/unit) & $($ million dollars) \\
Citrus pulp \& meal & 722,895 & Tons & $\$ 140.00$ & $\$ 101.2$ \\
Molasses & 57,058 & Tons & $\$ 125.00$ & $\$ 1.1$ \\
Citrus oil & $24,041,791$ & Pounds & & $\$ 27.7$ \\
\hline Total & & & $\$ 136$ \\
\hline \hline
\end{tabular}


Table 6. Summary of economic impacts of the Florida citrus industry, 2007-08.

\begin{tabular}{|c|c|c|c|c|c|c|c|}
\hline $\begin{array}{l}\text { Citrus Industry } \\
\text { Segment }\end{array}$ & $\begin{array}{r}\text { Economic } \\
\text { Impact } \\
\text { Type }\end{array}$ & Output & Employment & $\begin{array}{l}\text { Value } \\
\text { Added }\end{array}$ & $\begin{array}{l}\text { Labor } \\
\text { Income }\end{array}$ & $\begin{array}{c}\text { Other } \\
\text { Property } \\
\text { Income }\end{array}$ & $\begin{array}{r}\text { Indirect } \\
\text { Business } \\
\text { Taxes }\end{array}$ \\
\hline & & $($ million \$) & $(\text { jobs) })^{\star}$ & $($ million \$) & $($ million \$) & $($ million \$) & $\overline{(\text { million \$) }}$ \\
\hline \multirow{4}{*}{$\begin{array}{l}\text { Citrus fruit } \\
\text { production for } \\
\text { juice } \\
\text { processing }\end{array}$} & Total & 3,571 & 41,206 & 2,087 & 1,185 & 762 & 139 \\
\hline & Direct & 1,503 & 16,987 & 814 & 314 & 457 & 43 \\
\hline & Indirect & 434 & 9,600 & 283 & 230 & 37 & 16 \\
\hline & Induced & 1,634 & 14,620 & 989 & 641 & 268 & 80 \\
\hline \multirow{4}{*}{$\begin{array}{l}\text { Citrus fruit } \\
\text { production for } \\
\text { fresh } \\
\text { consumption }\end{array}$} & Total & 601 & 6,941 & 351 & 200 & 128 & 23 \\
\hline & Direct & 253 & 2,861 & 137 & 53 & 77 & 7 \\
\hline & Indirect & 73 & 1,617 & 48 & 39 & 6 & 3 \\
\hline & Induced & 275 & 2,463 & 167 & 108 & 45 & 13 \\
\hline \multirow{4}{*}{$\begin{array}{l}\text { Citrus juice } \\
\text { processing and } \\
\text { byproducts }\end{array}$} & Total & 4,319 & 24,556 & 1,920 & 1,218 & 504 & 111 \\
\hline & Direct & 2,080 & 6,522 & 644 & 411 & 142 & 4 \\
\hline & Indirect & 819 & 5,380 & 418 & 256 & 126 & 36 \\
\hline & Induced & 1,420 & 12,654 & 858 & 551 & 236 & 71 \\
\hline \multirow{4}{*}{$\begin{array}{l}\text { Fresh citrus } \\
\text { marketing } \\
\text { margins }\end{array}$} & Total & 415 & 3,124 & 261 & 164 & 60 & 37 \\
\hline & Direct & 184 & 1,055 & 120 & 70 & 23 & 26 \\
\hline & Indirect & 46 & 370 & 27 & 18 & 7 & 2 \\
\hline & Induced & 185 & 1,699 & 114 & 76 & 30 & 9 \\
\hline \multirow{4}{*}{$\begin{array}{l}\text { All segments of } \\
\text { citrus industry }\end{array}$} & Total & 8,906 & 75,828 & 4,619 & 2,767 & 1,454 & 310 \\
\hline & Direct & 4,020 & 27,425 & 1,715 & 848 & 699 & 80 \\
\hline & Indirect & 1,372 & 16,967 & 776 & 543 & 176 & 57 \\
\hline & Induced & 3,514 & 31,436 & 2,128 & 1,376 & 579 & 173 \\
\hline
\end{tabular}


Table 7. Economic impacts of the Florida citrus industry by major industry group, 2007-08.

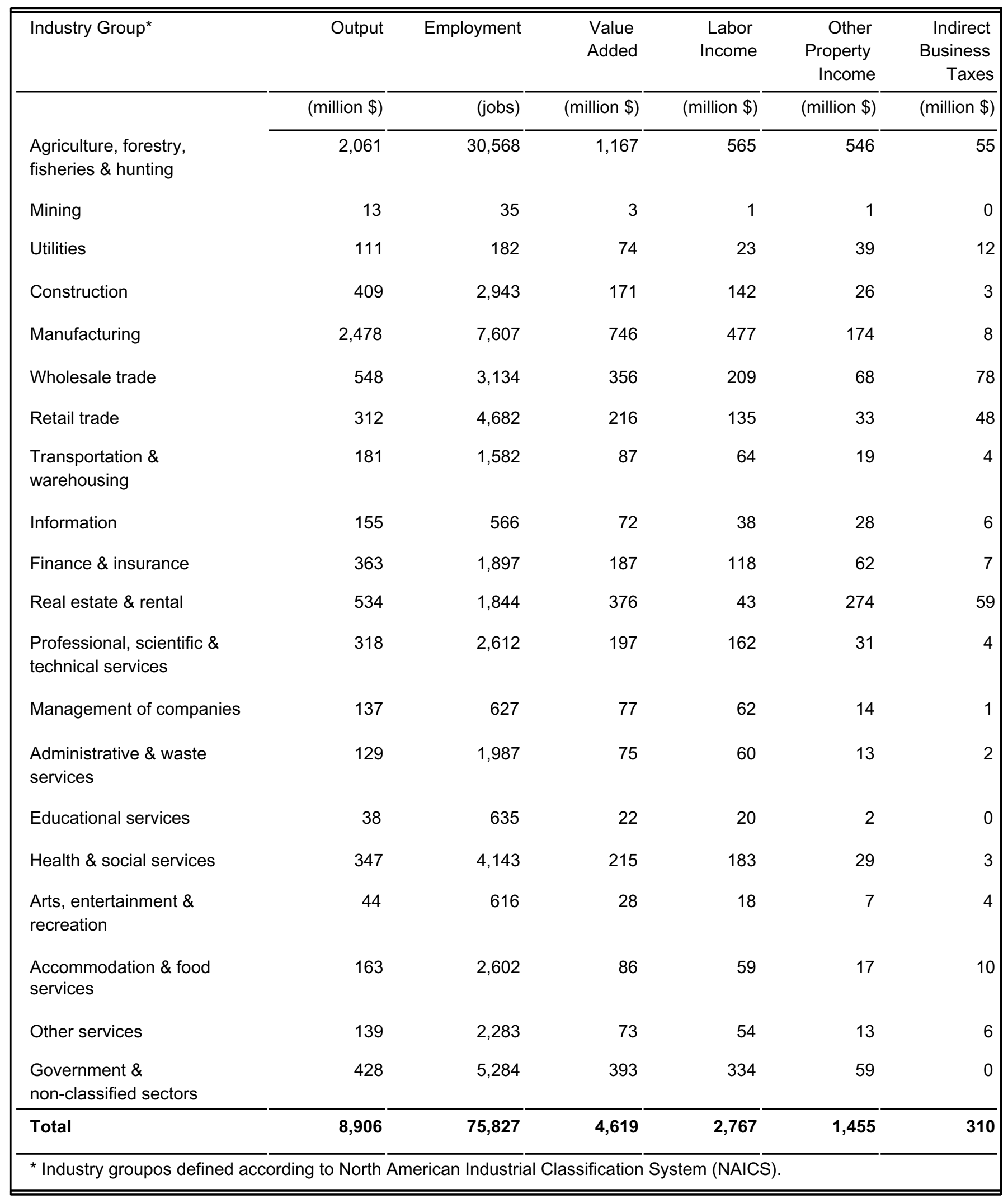




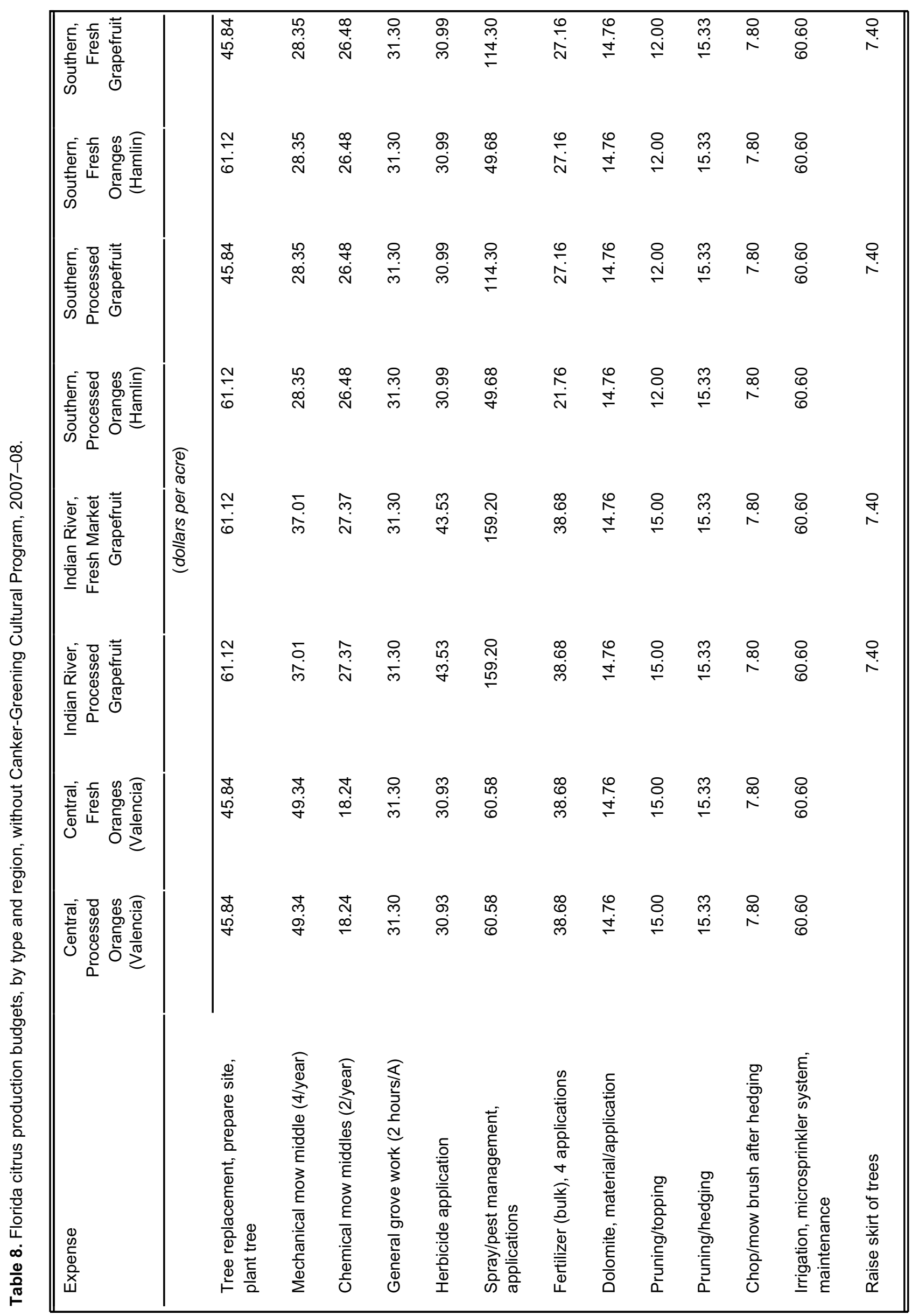




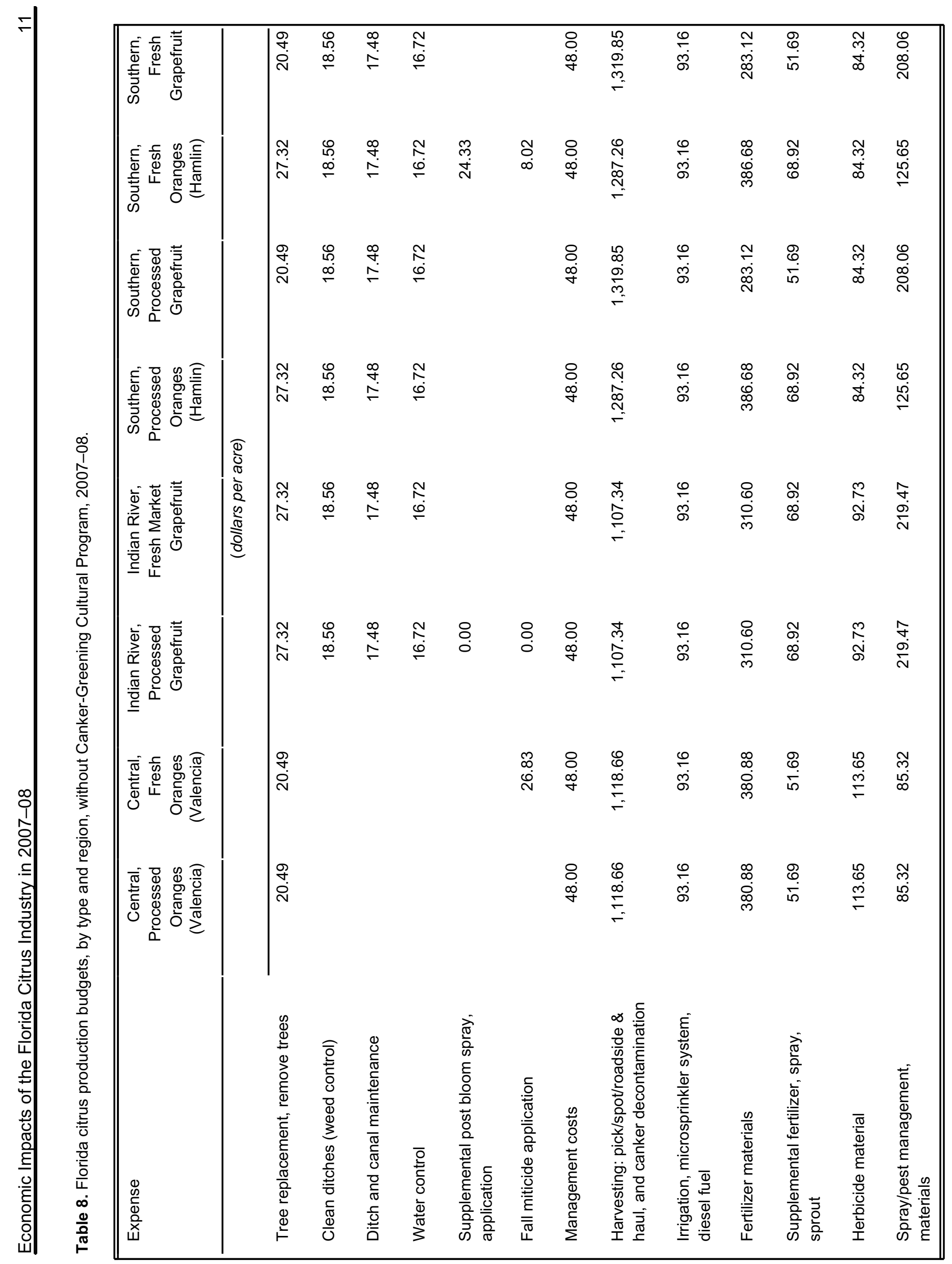




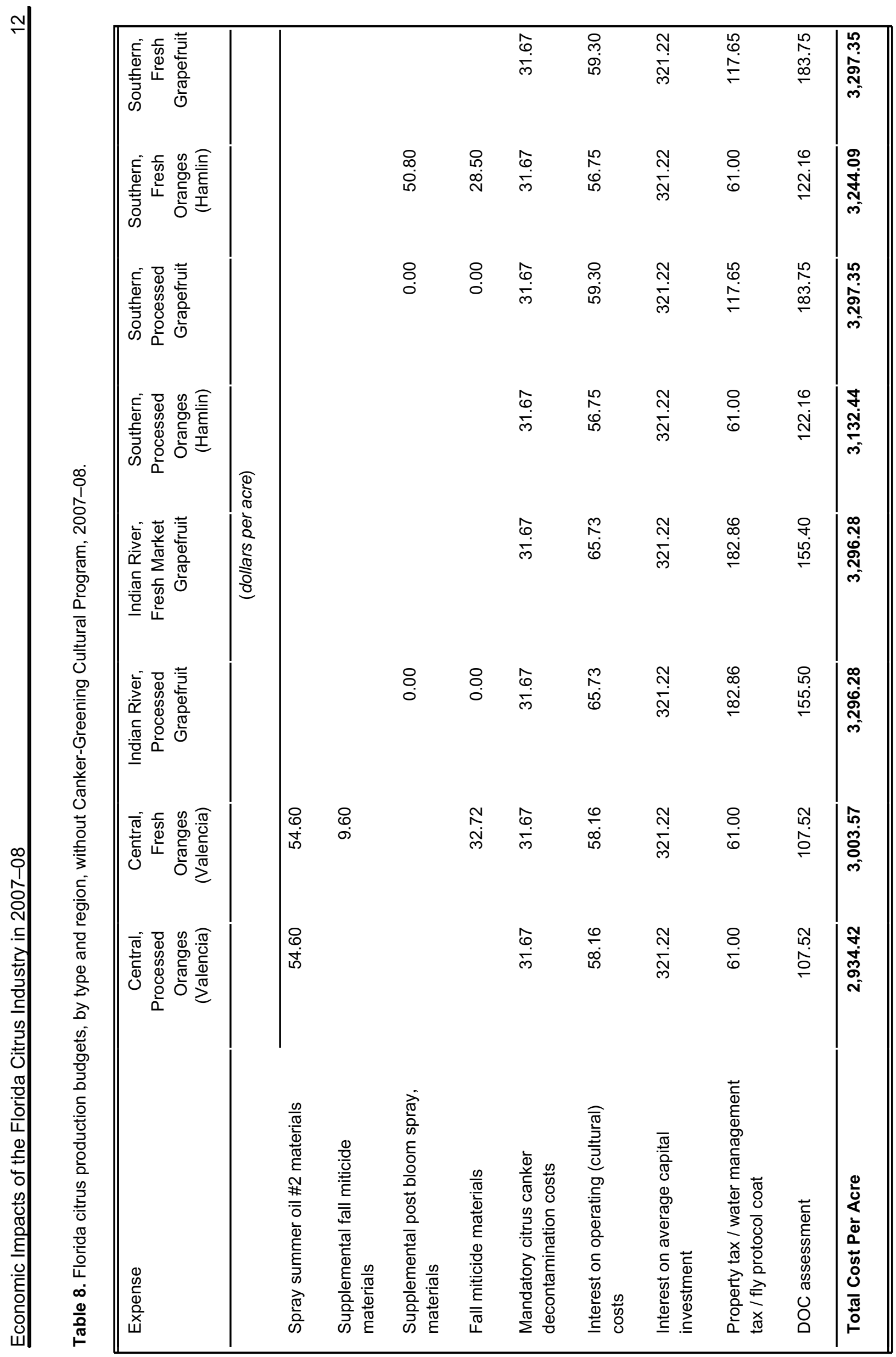




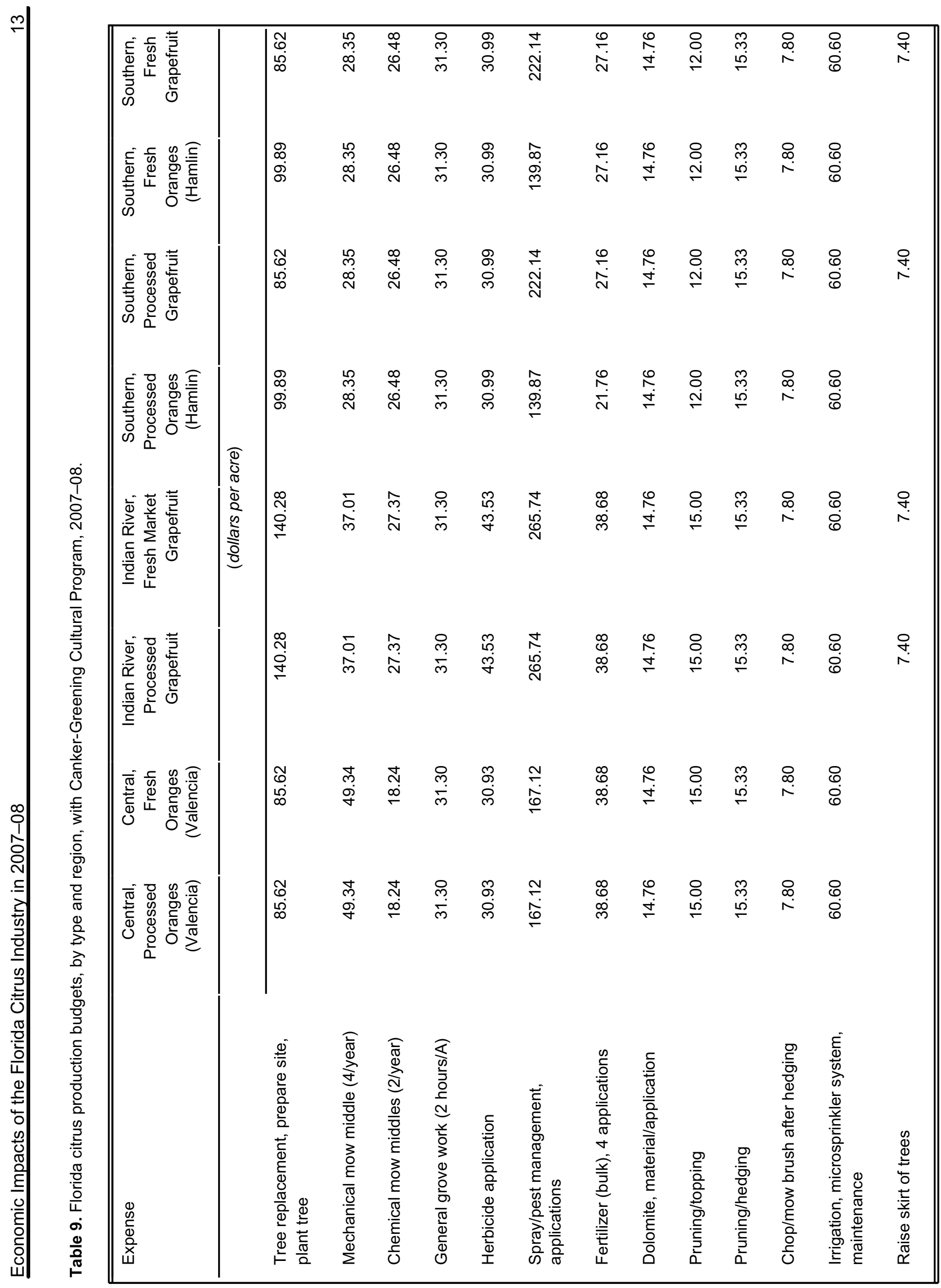




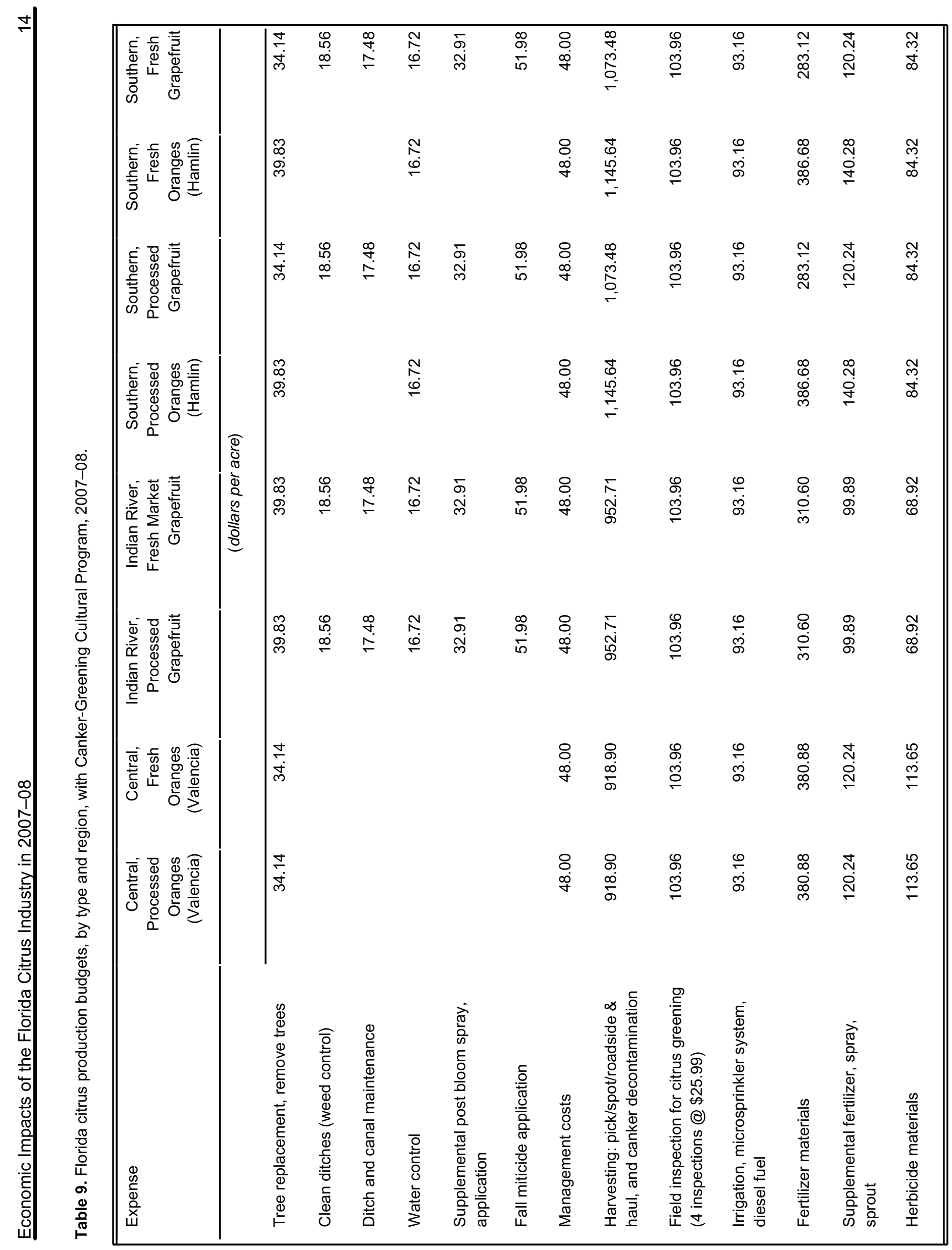




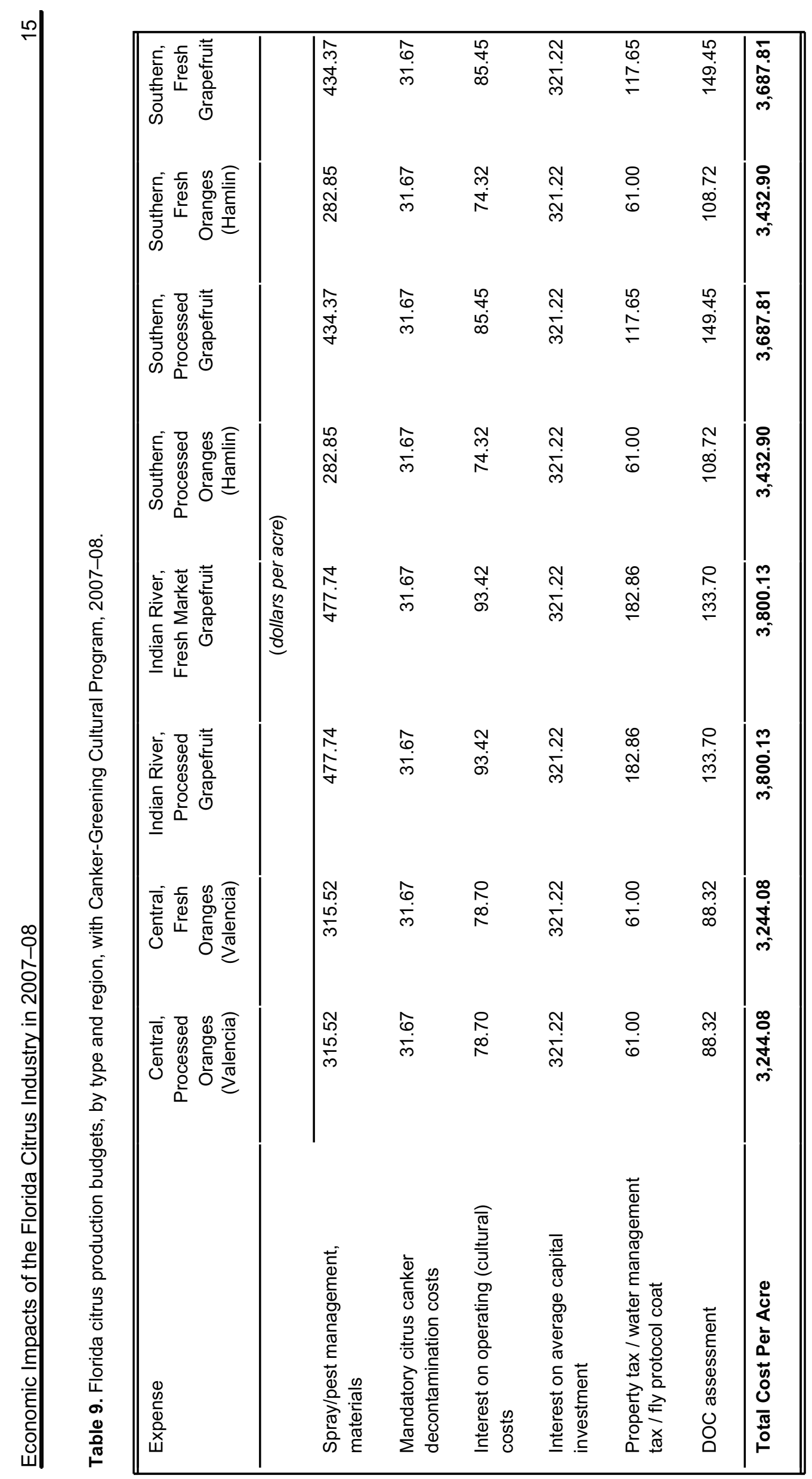

